\title{
Impact of acetate, pyruvate, and physiological state on respiration and respiratory quotients in Pseudomonas nautica
}

\author{
Sylvie O. Roy ${ }^{1, *}$, Ted T. Packard ${ }^{2}$, Elisa Berdalet ${ }^{2}$, Liliane St-Amand $^{1}$ \\ 'Institut Maurice-Lamontagne, Pêches et Océans, CP 1000, Mont-Joli, Québec G5H 3Z4, Canada \\ ${ }^{2}$ Institut de Ciències del mar (CSIC), P. Joan de Borbó, s/n, E-08039 Barcelona, Spain
}

\begin{abstract}
Physiological rates of $\mathrm{CO}_{2}$ production and $\mathrm{O}_{2}$ consumption, and the activities of isocitrate dehydrogenase (IDH) and the electron transfer system (ETS) were studied in the marine bacterium Pseudomonas nautica growing on acetate. In exponential growth, IDH and ETS activities were well coupled with $\mathrm{CO}_{2}$ production and $\mathrm{O}_{2}$ consumption rates, but in senescence they were uncoupled. Our results clearly show that under starvation conditions, IDH and ETS activities remained high even though their corresponding respiration rates dropped. The respiratory metabolism in the different physiological states of the acetate-grown cultures was compared with previous observations made in pyruvate-grown cultures. Time profiles of $\mathrm{CO}_{2}$ production and $\mathrm{O}_{2}$ consumption rates showed completely different respiratory fingerprints associated with the different carbon sources. Acetate-grown cultures showed an increase of respiratory quotients ( $R Q$ ) in the senescence phase whereas in pyruvate-grown cultures it stayed close to 1.0. On both carbon sources, respiration to respiratory capacity ratios were constant in exponential phase and decreased to almost zero after carbon source exhaustion. Our results clearly show the impact of physiological state and carbon sources on bacterial respiration rates.
\end{abstract}

KEY WORDS: $\mathrm{CO}_{2}$ production rates $\cdot \mathrm{O}_{2}$ consumption rates . Isocitrate dehydrogenase - Respiratory electron transfer system - ETS - Marine bacterium

The interest in bacterial respiration has been renewed by the need to quantify the role of bacteria in the ocean carbon cycle. Respiration represents an unambiguous measure of the loss of the organic carbon from the bacterial community (Jahnke \& Craven 1995). Of the various measures of this loss, $\mathrm{CO}_{2}$ production is the most direct. $\mathrm{CO}_{2}$ production rates have been measured at natural oceanic levels (Hansell et al. 1995). However, the technology is not available to directly measure natural oceanic $\mathrm{CO}_{2}$ production rates at time

•E-mail: st-amantl@dfo-mpo.gc.ca scales compatible with hydrographic, nutrient, and biomass levels. So, proxy methods must be used as Packard et al. (1988) did in their calculations of oceanic $\mathrm{CO}_{2}$ production rates from respiratory electron transfer system (ETS) activity. In an attempt to avoid conversion of $\mathrm{O}_{2}$ consumption rates, which are involved when ETS activity is used, to $\mathrm{CO}_{2}$ production rates, Berdalet et al. (1995) and Packard et al. (1996a) proposed the use of isocitrate dehydrogenase (IDH) activity as a direct measurement of the $\mathrm{CO}_{2}$ production rates. They based this proposal on the strong theoretical link between IDH and other Krebs cycle decarboxylases and the physiological rate of $\mathrm{CO}_{2}$ production (Walsh \& Koshland 1984). Furthermore, they supported their proposal by showing that IDH activity could be used to predict $\mathrm{CO}_{2}$ production rates in cultures of marine bacteria (Packard et al. 1996a).

The enzymatic basis of respiratory $\mathrm{O}_{2}$ consumption and $\mathrm{CO}_{2}$ production has long been understood. The $\mathrm{O}_{2}$ consumption is controlled by a nearly universal respiratory ETS (Keilin 1966); the $\mathrm{CO}_{2}$ production is controlled by 3 enzymes associated with the Krebs cycle (Holms 1986a, Berdalet et al. 1995). These enzymes are IDH (EC.1.1.1.42), $\alpha$-ketoglutarate dehydrogenase (KGDH, EC.1.2.7.3), and pyruvate dehydrogenase (PDH, EC.1.2.2.2). All 3 enzymes are required to decarboxylate carbohydrates, but fatty acids and most amino acids can be decarboxylated by IDH and $\mathrm{KGDH}$ without the action of PDH. During decarboxylation, the Krebs cycle also generates reducing equivalents that via the ETS lead to ATP production and $\mathrm{O}_{2}$ consumption, and in addition, supplies low molecular precursors for biosynthesis.

Micro-organisms can grow on a wide variety of carbon sources. However, growth based on 2 or 3 carbon molecules cannot be achieved by means of the Krebs cycle alone (Berdalet et al. 1995). For example, during 
acetate-based growth, both carbon atoms are lost through the Krebs cycle leaving no carbon to construct precursors for biosynthesis. In this situation, the glyoxylate cycle allows an organism to replenish the intermediates of the Krebs cycle (Holms 1986b). IDH is the branch point for the flow of carbon through the Krebs cycle to produce energy and $\mathrm{CO}_{2}$, and for the flow of carbon through the glyoxylate cycle to produce cell constituents. Holms \& Bennett (1971) and El-Mansi et al. (1985) showed that, in acetate-grown cultures of Escherichia coli, the glyoxylate cycle is activated and the IDH is partially inactivated. Inversely, in pyruvategrown cultures, the glyoxylate cycle is inactivated and the IDH is activated.

Even though the enzymatic basis of respiration is known, it is one thing to identify the reactions, but it is quite another to understand their control well enough to quantitatively reconstruct the physiological rates of $\mathrm{CO}_{2}$ production and $\mathrm{O}_{2}$ consumption of whole celis from measurements of enzyme activities. Here, we investigate the coupling of the activity of respiration enzymes and physiological respiration rates in acetategrown Pseudomonas nautica cultures. Our enzymological, physiological and biomass measurements are used to calculate time courses of respiratory quotients (RQ), respiratory enzyme ratios, and respiration to respiratory capacity ratios in different growth phases. We report that the physiological state of the bacteria cultures and the organic carbon sources affect the physiological respiration rates.

Materials and methods. Experimental design: In order to demonstrate the degree of association between respiratory enzymes activities and physiological respiration rates in different stages of bacterial growth, time profile experiments (1 d) were run on batch cultures that were maintained on acetate at $22^{\circ} \mathrm{C}$. Every $2 \mathrm{~h}$, through exponential growth, steady state and senescence, 2 flasks were randomly chosen and $25 \mathrm{ml}$ samples were transferred to the Oxymax flasks for the respiration measurements. After $1 \mathrm{~h}$, when the respiration measurements were completed, the remaining culture in the chosen flasks was sampled for protein, ETS activity, IDH activity, and acetate. Growth was monitored from absorbance at $550 \mathrm{~nm}$ (OD550). Our results were compared with published results of identically performed experiments on pyruvate-grown Pseudomonas nautica cultures that were described by Packard et al. (1996a).

Bacterial cultures: Pseudomonas nautica (Strain 617), an oil-degrading bacterium isolated from the Gulf of Fos (France), was provided by Dr P. Bonin (Centre d'Océanologie, Marseille, France). Batch cultures were cultivated as described in Packard et al. (1996a,b). Fig. 1 shows the biomass development in terms of protein. The initial concentration of the carbon source in the culture media was either $30 \mathrm{mM}$ sodium acetate or $20 \mathrm{mM}$ pyruvate. Growing on acetate, $P$. nautica entered exponential phase during the first 2 to $3 \mathrm{~h}$. of the experiment and maintained a growth rate of $0.24 \mathrm{~h}^{-1}$ until the 14 th hour when the culture reached stationary phase (Fig. 1). Exponential growth ended slightly prior to acetate exhaustion. Growth on pyruvate followed a similar pattern (Packard et al. 1996a). The final biomass was higher on acetate $(339 \pm 4 \mathrm{mg}$ protein $\left.\mathrm{l}^{-1}\right)$ than on pyruvate $(288 \pm 10$ and $303 \pm 9 \mathrm{mg}$ protein $1^{-1}$; Packard et al. $\left.1996 \mathrm{a}, \mathrm{b}\right)$. Protein was related to OD550 in acetate-grown cultures by the equation: protein $=2.4+244.3\left(\right.$ OD 550), $\mathrm{I}^{2}=0.940$.

Biochemical parameters: Biochemical sampling was accomplished as in Berdalet et al. (1995) and Packard et al. $(1996 \mathrm{a}, \mathrm{b})$. Acetate in the supernatant fluid was measured in its acid form ( $\mathrm{pH} 2.0)$ at $210 \mathrm{~nm}$ by high performance liquid chromatography (HPLC) as described by Berdalei el al. (1995). Protein analysis was performed according to Berdalet et al. (1995) and reported as $\mathrm{mg}$ protein $\mathrm{l}^{-1}$. The IDH extraction buffer and the IDH activity assay are described in Berdalet et al. (1995). A standard curve based on NADPH concentrations and the 1:1 stoichiometry between $\mathrm{CO}_{2}$ and NADPH production was used to convert the absorbance at $340 \mathrm{~nm}$ measurements to $\mu \mathrm{mol} \mathrm{CO}_{2}$; results are reported as $\mu \mathrm{mol} \mathrm{CO}_{2} \mathrm{~min}^{-1} \mathrm{l}^{-1}$ and each data point represents 4 analyses. ETS activity was measured by the kinetic assay described in Packard et al. (1996b). Results are reported as $\mu \mathrm{mol} \mathrm{O}_{2} \mathrm{~min}^{-1} \mathrm{l}^{-1}$ and each data point represents 4 analyses

Respiration measurements: Respiratory $\mathrm{CO}_{2}$ production $\left(\mathrm{R}_{\mathrm{CO}_{2}}\right)$ and respiratory $\mathrm{O}_{2}$ consumption $\left(\mathrm{R}_{\mathrm{O}_{2}}\right)$ were simultaneously measured using a Micro-Oxymax (Columbus Instruments International Corporation,

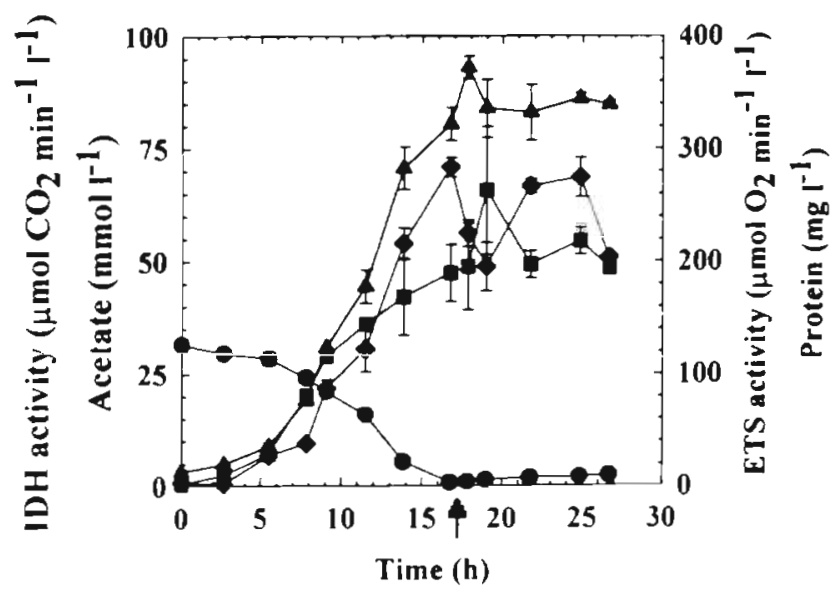

Fig. 1. Pseudomonas nautica. Acetate time-course experiment showing measurements of protein $(\boldsymbol{\Lambda})$, acetate ( $)$, IDH activity $(\boldsymbol{\square})$, and ETS activity $(\bullet) .(\uparrow)$ Time of acetate exhaustion in the culture media 
Columbus, USA). The sampling and measurements were performed as in Berdalet et al. (1995). During the measurements, the cultures were maintained at $22^{\circ} \mathrm{C}$ and were continuously shaken in order to optimize gas exchange. Oxygen limitation was avoided by periodic replenishment of the air in the headspace above the samples between rate measurements. Measurements over 30 min intervals were made in duplicate and referenced against a baseline and a control. The $\mathrm{CO}_{2}$ and the $\mathrm{O}_{2}$ sensors were calibrated against high precision gas standards. Here, $\mathrm{R}_{\mathrm{CO}_{2}}$ refers to $\mathrm{CO}_{2}$ generated by intact bacteria suspended in their growth medium; the units are $\mu \mathrm{mol} \mathrm{CO}_{2} \mathrm{~min}^{-1} 1^{-1} \cdot \mathrm{R}_{\mathrm{O}_{2}}$ refers to $\mathrm{O}_{2}$ used under the same conditions and the units are $\mu \mathrm{mol} \mathrm{O}_{2}$ $\min ^{-1} \mathrm{l}^{-1}$.

Results. Time profiles of protein, acetate, IDH activity, ETS activity, $\boldsymbol{R}_{\mathrm{CO}_{2}}$ and $\boldsymbol{R}_{\mathrm{O}_{2}}$ : Time profile observations in the bacteria culture are shown in Fig. 1. Within $24 \mathrm{~h}$, the acetate in the culture decreased from $30 \mathrm{mmol} \mathrm{l}^{-1}$ to nearly zero and the protein increased inversely from $10 \mathrm{mg} \mathrm{l}^{-1}$ to $340 \mathrm{mg} \mathrm{l}^{-1}$. IDH and ETS activities tracked protein throughout all phases of growth. When the activity of either enzyme was plotted against protein, the correlation $\left(\mathrm{r}^{2}\right)$ was always greater than 0.912 . In contrast to the enzyme activities, $\mathrm{R}_{\mathrm{CO}_{2}}$ and $\mathrm{R}_{\mathrm{O}_{2}}$ did not follow the protein profile throughout all growth phases since after exponential growth they decreased (Fig. 2). In the exponential phase and early steady state, $R_{\mathrm{CO}_{2}}$ and $\mathrm{R}_{\mathrm{O}_{2}}$ rates were positively correlated with IDH and ETS activities, respectively (Table 1). However, when the cells entered the stationary phase and acetate was exhausted, a dramatic uncoupling between respiration and the enzyme activities occurred (Figs. $1 \& 2$ ).

Table 1 Pseudomonas nautica. IDH $=f$ (protein), $\mathrm{R}_{\mathrm{CO}_{2}}=$ $f(\mathrm{IDH}), \mathrm{ETS}=f$ (protein), $\mathrm{R}_{\mathrm{O}_{2}}=f($ ETS $), \mathrm{IDH}=f($ ETS $)$ and $\mathrm{R}_{\mathrm{CO}_{2}}$ $=f\left(\mathrm{R}_{\mathrm{O}_{2}}\right)$ relationships by linear regression analysis on data from acetate- or pyruvate-grown cultures. The acetate-based relationships are calculated from the data shown in Fig. 1. The slopes of regression equations are given with their standard errors. All regressions were forced through the origin

\begin{tabular}{|c|c|c|}
\hline Relation & Acetate & Pyruvate \\
\hline $\mathrm{IDH}=f(\text { protein })^{\mathrm{b}}$ & $0.14 \pm 0.01$ & $0.28 \pm 0.01$ \\
\hline $\mathrm{R}_{\mathrm{CO}_{2}}=f(\mathrm{IDH})^{\mathrm{C}}$ & $0.48 \pm 0.02$ & $0.53 \pm 0.02$ \\
\hline $\mathrm{ETS}=f(\text { protein })^{\mathrm{b}}$ & $0.73 \pm 0.06$ & $0.69 \pm 0.02$ \\
\hline $\mathrm{R}_{\mathrm{O}_{2}}=f(\mathrm{ETS})^{\mathrm{c}}$ & $0.40 \pm 0.08$ & $0.24 \pm 0.01$ \\
\hline $\mathrm{IDH}=f(\mathrm{ETS})^{\mathrm{b}}$ & $0.17 \pm 0.02$ & $0.39 \pm 0.01$ \\
\hline $\mathrm{R}_{\mathrm{CO}_{2}}=f\left(\mathrm{R}_{\mathrm{O}_{2}}\right)^{\mathrm{c}}$ & $0.36 \pm 0.04$ & $0.77 \pm 0.05$ \\
\hline \multicolumn{3}{|c|}{$\begin{array}{l}{ }^{a} \text { The pyruvate-based relationships are calculated from the } \\
\text { results of } 2 \text { separate experiments shown in Packard et al. } \\
\text { (1996a,b) } \\
\text { b These relationships hold for all growth phases }\left(r^{2}>0.91\right) \\
\text { c These relationships hold for the exponential phase }\left(r^{2}>0.90\right)\end{array}$} \\
\hline
\end{tabular}
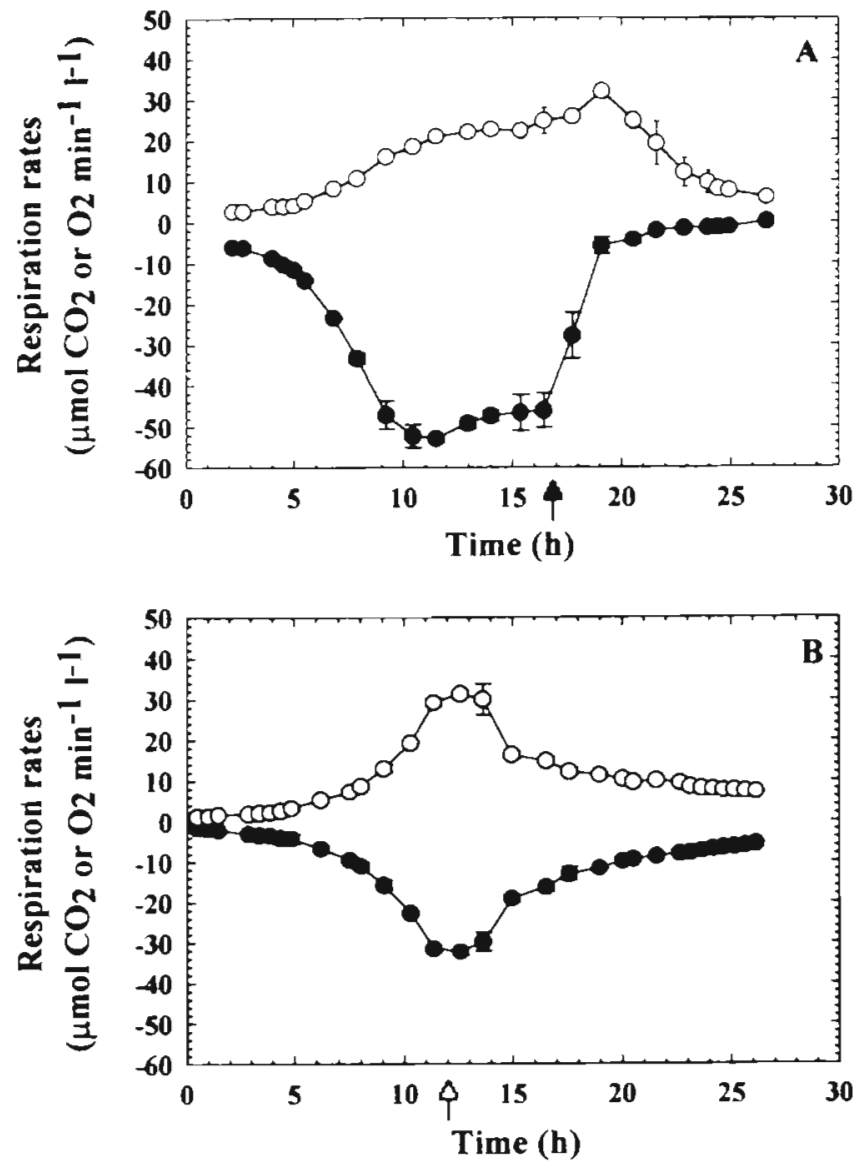

Fig. 2. Pseudomonas nautica. Simultaneous measurements by the Oxymax of $\mathrm{R}_{\mathrm{CO}_{2}}(\mathrm{O})$ and $\mathrm{R}_{\mathrm{O}_{2}}(\bullet)$ : (A) original respiration data for the acetate-grown cultures shown in Fig. 1 and $(B)$ original data for the pyruvate-grown culture presented in Packard et al. (1996a,b). ( $\$$ ) Time of acetate exhaustion and

$(\varphi)$ time of pyruvate exhaustion in the culture media

Physiological respiration rates, $R Q$ and respiratory enzyme ratios: Fig. 2 compares $\mathrm{R}_{\mathrm{CO}_{2}}$ and $\mathrm{R}_{2}$ time profiles for Pseudomonas nautica growing on acetate and on pyruvate. This figure shows data from the acetatebased experiment presented in Fig. 1 and from the pyruvate-based experiment presented by Packard et al. (1996a). In the acetate-grown culture, the 2 respiration rates tracked each other during exponential phase with a slope $(m)=0.36\left(\mathrm{r}^{2}=0.973\right)$ (Table 1). However, as soon as acetate was exhausted, $\mathrm{R}_{\mathrm{O}_{2}}$ declined and the 2 rates became uncoupled (Fig. 2A) whereas $\mathrm{R}_{\mathrm{CO}_{2}}$ declined $2 \mathrm{~h}$ later. In the pyruvate-grown culture, $\mathrm{R}_{\mathrm{CO}_{2}}$ and $\mathrm{R}_{\mathrm{O}_{2}}$ were highly correlated, not only in the exponential phase, but throughout all phases (Fig. 2B) with $m=0.77\left(\mathrm{r}^{2}=0.937\right)$ (Table 1$)$.

The time courses of RQ, calculated on a point-bypoint basis, are shown in Fig. 3 for the acetate- and pyruvate-grown cultures. Although, in exponential phase, both RQs stayed below 1.0, the RQ in the pyru- 


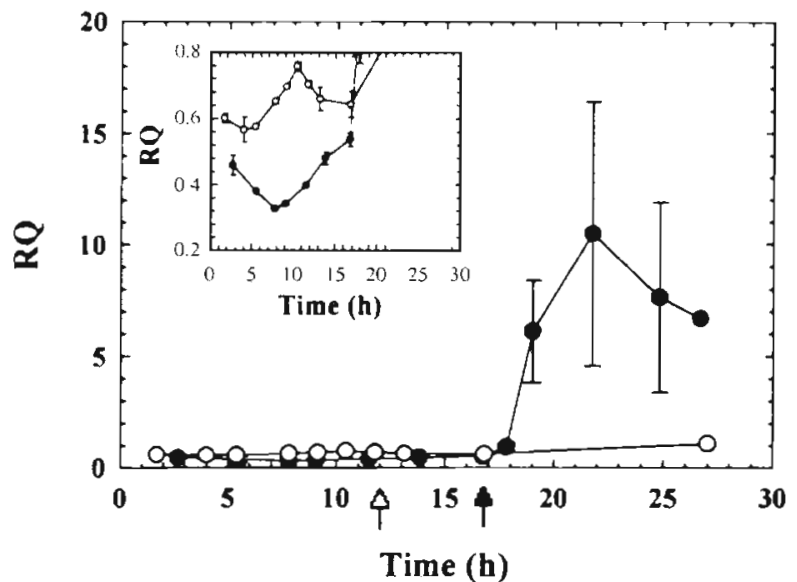

Fig. 3. Pseudomonas nautica. Time profiles of respiratory quotient (RQ) ( $\mu$ mol $\mathrm{CO}_{2}$ produced $\mu \mathrm{mol}^{-1} \mathrm{O}_{2}$ consumed) in acetate- $(\bullet)$ and in pyruvate-grown cultures $(0)$. ( $\uparrow$ ) Time of acetate exhaustion and $(\hat{\uparrow})$ time of pyruvate exhaustion in the culture media. Original data for the pyruvate-grown culture are presented in Packard et al. $(1996 \mathrm{a}, \mathrm{b})$

vate culture was always higher. In senescence phase, the $R Q$ in the pyruvate culture increased slightly from its level in exponential phase but, in the acetate culture, it rose to a value greater than 10 . Regression analysis of RQ time courses in exponential growth could not detect any time-dependent changes at $p<0.001$.

IDH and ETS activities tracked each other and, consequently, were highly correlated in all phases of both cultures with $m=0.17\left(\mathrm{r}^{2}=0.910\right)$ for the acetategrown culture and $m=0.39\left(\mathrm{r}^{2}=0.975\right)$ for the pyruvate-grown culture (Table 1). The time profiles of the ratio IDH activity/ETS activity calculated on a pointby-point basis represent the capacity for $\mathrm{CO}_{2}$ production to the capacity for $\mathrm{O}_{2}$ consumption. This was constant throughout both experiments and regression analysis of IDH activity/ETS activity ratios in all phases could not detect any time-dependent changes at $\mathrm{p}<$ 0.001 .

Ratios of respiration rates to respiratory capacity: $\mathrm{R}_{\mathrm{O}_{2}}$ and ETS activity were highly correlated in the exponential phase of both cultures and yielded regression equations where $m=0.40\left(\mathrm{r}^{2}=0.902\right)$ for acetateand $m=0.24\left(\mathrm{r}^{2}=0.980\right)$ for pyruvate-grown cultures (Table 1). Time profiles of the $\mathrm{R}_{\mathrm{O}_{2}}$ /ETS activity ratio calculated for Pseudomonas nautica cultures grown on acetate or pyruvate are shown in Fig. 4A. The $\mathrm{R}_{\mathrm{O}_{2}}$ /ETS activity ratios decreased slowly during the exponential phase for the cultures grown on the 2 carbon sources. These ratios then decreased to nearly zero after acetate or pyruvate had disappeared from the culture medium.

During the exponential phase of both cultures, $\mathrm{R}_{\mathrm{CO}_{2}}$ and IDH activity were highly correlated, with $m=0.48$
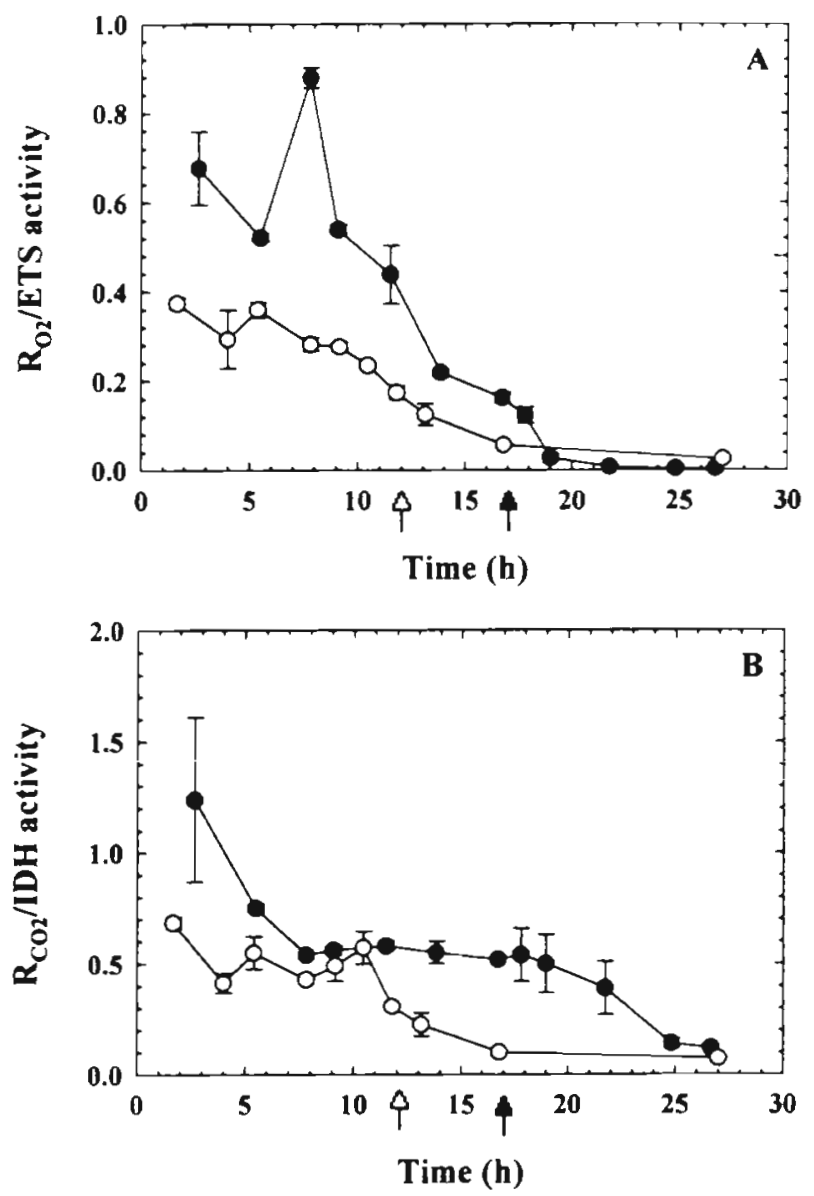

Fig. 4. Pseudomonas nautica. Time profiles of: (A) $\mathrm{R}_{\mathrm{O}_{2}}$ /ETS activity ratios (unitless) and (B) $\mathrm{R}_{\mathrm{CO}_{2}} / \mathrm{IDH}$ activity ratios (unitless) in acetate- ( ) and in pyruvate-grown cultures (0). ( $\uparrow)$ Time of acetate exhaustion and $(\$)$ time of pyruvate exhaustion in the culture media. Original data for the pyruvategrown culture presented in Packard et al. $(1996 a, b)$

$\left(\mathrm{r}^{2}=0.991\right)$ for acetate and $m=0.53\left(\mathrm{r}^{2}=0.984\right)$ for pyruvate-grown cultures (Table 1). Fig. 4B shows the time profiles of $\mathrm{R}_{\mathrm{CO}_{2}} / \mathrm{IDH}$ activity calculated for Pseudomonas nautica cultures grown on acetate (data from Fig. 1) and pyruvate (data from Packard et al. $1996 \mathrm{a}, \mathrm{b})$. In the acetate-grown cultures, the ratio $\mathrm{R}_{\mathrm{CO}_{2}} / \mathrm{IDH}$ activity was constant from $8 \mathrm{~h}$ after inoculation to the end of the exponential phase. In the pyruvate-grown cultures, that ratio was constant from the inoculation to the end of the exponential phase. After the exponential phase, the ratio started to decrease before pyruvate exhaustion in the pyruvate-grown cultures, whereas in the acetate-grown cultures the ratio stayed stable for about $5 \mathrm{~h}$ after acetate had disappeared from the culture medium; then it started to decrease.

Discussion. Respiratory enzyme activities: In the acetate experiment, the respiratory enzyme activities 
(IDH and ETS) tracked cellular protein throughout the exponential and steady state (Fig. 1) and any 1 of the 3 variables could have been used as an estimator of the others. In an earlier study, ETS activity was positively correlated with protein in growing $P_{\text {seudomonas }}$ perfectomarinus cultures (Packard et al. 1983). However, in a study of $P$. nautica grown on pyruvate, longer term experiments clearly showed that the relation became less reliable when the cells had been starved for more than $3 \mathrm{~d}$. Our observations support the hypothesis presented by Packard et al. (1996a, b) suggesting that both IDH and ETS are constitutive and that during starvation these enzyme systems are not inactivated or degraded after the carbon source has been exhausted, but rather are in an alert status. Our findings also confirm those of Packard et al. $(1983,1996 a, b)$ suggesting that under appropriate conditions these respiratory enzyme activity measurements could serve as proxies for living biomass in the absence of protein measurements.

Many bacteria strains are known to have the capability to maintain their enzymatic machinery when the carbon source is exhausted. Indeed, uncoupling of physiological respiration rates from enzymology with carbon source exhaustion was observed in Vibrio natriegens cultures (Nystrom et al. 1990, Berdalet et al. 1995), in Pseudomonas nautica cultures (Packard et al. 1996a) and, in less detail, in other marine bacteria by Christensen et al. (1980). Our results clearly show the capability of $P$. nautica to maintain IDH and ETS activities after $10 \mathrm{~h}$ of acetate exhaustion (Fig. 1). In the marine environment, characterized by highly variable level of organic nutrients, the ability to remain primed for substrate availability would facilitate recovery when nutrient conditions become favorable.

Physiological respiration rates, RQs and respiratory enzyme ratios: A striking observation of this study was the difference between the respiratory time profile of $\mathrm{R}_{\mathrm{CO}_{2}}$ and $\mathrm{R}_{\mathrm{O}_{2}}$ in the acetate-grown culture presented here and the equivalent respiratory time profile in the pyruvate-grown culture of Packard et al. (1996a). Paired time-course measurements of $\mathrm{R}_{\mathrm{CO}_{2}}$ and $\mathrm{R}_{\mathrm{O}_{2}}$ are rare in the literature. Usually, $\mathrm{R}_{\mathrm{O}_{2}}$ is measured and, if $\mathrm{R}_{\mathrm{CO}_{2}}$ is desired, it is then calculated from the $\mathrm{R}_{\mathrm{O}_{2}}$ using a constant RQ. It is clear from Fig. 2 that Pseudomonas nautica cultures grown on acetate or pyruvate gave completely different respiration patterns. Differences in patterns of the respiratory time courses were also observed for Vibrio natriegens cultures growing on acetate or pyruvate (Berdalet et al. 1995). Since acetate and pyruvate are products of lipid and carbohydrate metabolism, respectively, the results suggest that paired measurements of $\mathrm{R}_{\mathrm{CO}_{2}}$ and $\mathrm{R}_{\mathrm{O}_{2}}$ could serve as a diagnostic for detecting different types of metabolism in the field. They could also be used to detect qualita- tive differences in the dissolved organic carbon (DOC) in aquatic environments. High RQ would indicate carbohydrate metabolism and thus would indicate a strong presence of carbohydrates in the DOC. Low $R Q$ would indicate lipid metabolism and consequently the presence of lipids in the DOC.

There is a dearth of information on the temporal variability in RQ and in spite of the work of Parsons et al. (1984) and Griffith et al. (1990), not much is known about the variability within different carbon sources. Here, we present simultaneous measurements of $R_{\mathrm{CO}_{2}}$ and $\mathrm{R}_{\mathrm{O}_{2}}$ and direct calculations of $\mathrm{RQ}$ as functions of time and physiological state. Our results show that, in Pseudomonas nautica cultures, the RQ is always lower than 1.0 before acetate or pyruvate are exhausted. However, in the acetate-grown culture, when acetate was exhausted, the $R Q$ rose above 1.0 and reached a value higher than 10 . That increase of $R Q$ was caused by a fast reduction of $\mathrm{R}_{\mathrm{O}_{2}}$ after acetate exhaustion when $\mathrm{R}_{\mathrm{CO}_{2}}$ was still high. The time variations of $R Q$ while the cultures passed from a well-nourished state to a nutrient-starved state argue for a reconsideration of the practice of assuming a constant RQ of 1.0.

Since the $R Q$ variations are a reflection of the physiological respiration rates ratio, would the respiratory enzyme ratio resemble the $R Q$ and show similar variations in the senescence phase? Could the respiratory enzyme concentrations be responsible for the $R Q$ difference observed in the senescence phase of the cultures? The IDH activity/ETS activity ratios did not ascend like the $\mathrm{RQ}$ did when the acetate was exhausted in the acetate-grown culture (not shown). The ratio was nevertheless higher in the pyruvategrown culture, reflecting the higher IDH content in this culture (Table 1 and Holms 1986a). This is also consistent with observations by El-Mansi et al. (1985) that, during growth on acetate, IDH is partially inactivated to facilitate glyoxylate cycle activity. This behavior of IDH activity/ETS activity ratios in acetate- and pyruvate-grown cultures suggests that respiratory enzyme concentrations are not responsible for $R Q$ differences observed in senescence in acetate-grown culture. However, the different values of enzyme activity ratios found for acetate- and pyruvate-grown cultures may be associated with differences in the IDH substrate-controlled activity.

Respiration and respiratory capacity: $\mathrm{R}_{\mathrm{O}_{2}}$ /ETS activity ratios were shown to vary as functions of the physiological phases of bacterial cultures by Christensen et al. (1980). Indeed, in Christensen's study, $\mathrm{R}_{\mathrm{O}_{2}}$ ETS activity ratios were always higher in exponential phase than in senescence phase. Our $\mathrm{R}_{\mathrm{O}_{2}}$ /ETS activity time profiles followed the same trend. Then, comparing $\mathrm{R}_{\mathrm{O}_{2}}$ /ETS activity ratios during the exponential phase, we noticed that the $\mathrm{R}_{\mathrm{O}_{2}}$ /ETS activity ratio in the 
acetate-grown culture was almost twice the ratio in the pyruvate-grown culture. Since ETS activity/protein levels were similar in both cultures, it becomes evident that the observed difference in $\mathrm{R}_{\mathrm{O}_{2}}$ /ETS activity ratios in exponential phase was caused by a higher $\mathrm{R}_{\mathrm{O}_{2}}$ in the acetate-grown culture. This phenomena was also observed by Berdalet et al. (1995) in the Vibrio natriegens cultures. ETS activity measurements are used to assess mesoscale variations of $\mathrm{R}_{\mathrm{O}_{2}}$ in the water column. Packard et al. (1996b) pointed out that a better understanding of the nutritional state of the studied population is needed for accurate interpretation of ETS measurements in the ocean. The physiological phasedependent variability of $\mathrm{R}_{\mathrm{O}_{2}}$ /ETS activity ratios observed in the acetate- or pyruvate-grown Pseudomonas nautica cultures supports that affirmation.

ETS measurements have been used to calculate $\mathrm{R}_{\mathrm{CO}_{2}}$ in deep waters (Savenkoff et al. 1995, Packard et al. 1988). Nevertheless, the problems associated with these $\mathrm{R}_{\mathrm{CO}_{2}}$ calculations have prompted Packard et al. (1996a) to propose a kinetic approach to estimate $\mathrm{R}_{\mathrm{CO}_{2}}$ from IDH measurements. Prior to this investigation, $\mathrm{R}_{\mathrm{CO}_{2}} / \mathrm{IDH}$ activity values for marine bacteria were unknown. $\mathrm{R}_{\mathrm{CO}_{2}}$ /IDH activity ratio can be defined as the percent utilization of the respiratory capacity. In the exponential phase of the acetate- or pyruvate-grown Pseudomonas nautica cultures, the cells were respectively using 48 and $53 \%$ of their respiratory $\mathrm{CO}_{2}$ production capacity (Table 1). This observation shows that the percent utilization of the respiratory capacity was not affected by the different carbon source in exponential phase. However, the time profiles of $\mathrm{R}_{\mathrm{CO}_{2}} / \mathrm{IDH}$ activity in acetate- or pyruvate-grown $P$. nautica cultures (Fig. 4B) showed a decrease in the senescence phase that was associated with the decrease of $\mathrm{R}_{\mathrm{CO}_{2}}$ in that phase (Figs. $1 \& 2$ ). In the pyruvate culture, the decrease of $\mathrm{R}_{\mathrm{CO}_{2}}$ was associated with pyruvate exhaustion. On the other hand, in the acetate culture $\mathrm{R}_{\mathrm{CO}_{2}}$ was maintained for a few hours after acetate exhaustion. This suggested that the metabolism was based on excreted matter during that period (Berdalet et al. 1995). Our findings clearly demonstrate that the $\mathrm{R}_{\mathrm{CO}_{2}}$ /IDH activity ratio (Table 1 ) can be used to estimate $\mathrm{R}_{\mathrm{CO}_{2}}$ from IDH measurements only when the cells are in a well-nourished state. As soon as the cells enter starvation, the kinetic approach (Packard et al. 1996a) becomes a more accurate tool to estimate $\mathrm{R}_{\mathrm{CO}_{2}}$.

Acknowledgements. We thank the Spanish Ministry of Science for granting the post-doctoral fellowship to E.B., Dr K. Lee for his encouragement. B. Lagacé for dedicated work in the laboratory, and Dr J.P. Gagne who ran the HPLC analysis.

Editorial responsibility: Faroog Azam,

La Jolla, California, USA

\section{LITERATURE CITED}

Berdalet E, Packard T, Lagacé B, Roy S, St-Amand L, Gagné JP (1995) $\mathrm{CO}_{2}$ production, $\mathrm{O}_{2}$ consumption, and isocitrate dehydrogenase in the marine bacterium Vibrio natriegens. Aquat Microb Ecol 9:211-217

Christensen JP, Owens TG, Devol AH, Packard TT (1980) Respiration and physiological state in marine bacteria. Mar Biol 55:267-276

El-Mansi EMT, Nimmo HG, Holms WH (1985) The role of isocitrate in control of the phosphorylation of isocitrate dehydrogenase in Escherichia coli ML308. FEBS Lett 183: 251-255

Griffith PC, Douglas DJ, Wainright SC (1990) Metabolic activity of size-fractionated microbial plankton in estuarine, nearshore and continental shelf waters of Georgia. Mar Ecol Prog Ser 59:263-270

Hansell DA, Bates NR, Gundersen K (1995) Mineralization of dissolved organic carbon in the Sargasso Sea. Mar Chem $51: 201-212$

Holms WH (1986a) The central metabolic pathways of Escherichia coli: relationship between flux and control at a branch point, efficiency of conversion to biomass, and excretion of acetate. Curr Top Cell Regul 28:69-105

Holms WH (1986b) Evolution of the glyoxylate bypass in Escherichia coli-an hypothesis which suggests an alternative to the Krebs cycle. FEMS Microbiol Lett 34 $123-127$

Holms WH, Bennett PM (1971) Regulation of isocitrate dehydrogenase activity in Escherichia coli on adaptation to acetate. $J$ Gen Microbiol 65:57-68

Jahnke RA, Craven DB (1995) Quantifying the role of heterotrophic bacteria in the carbon cycle: a need for respiration rate measurements. Limnol Oceanogr 40:436-441

Keilin D (1966) The history of cell respiration and cytochrome. Cambridge University Press, Cambridge

Nystrom T, Flardh K, Kjelleberg S (1990) Responses to multiple-nutrient starvation in marine Vibrio sp. strain CCUG 15956. Bacteriol 172:7085-7097

Packard TT, Garfield PC, Martinez R (1983) Respiration and respiratory enzyme activity in aerobic and anaerobic cultures of the marine denitrifying bacterium, Pseudomonas perfectomarinus. Deep-Sea Res 30:227-243

Packard TT, Denis M, Rodier M, Garfield P (1988) Deepocean metabolic $\mathrm{CO}_{2}$ production: calculations from ETS activity. Deep-Sea Res 35:371-382

Packard T, Berdalet E, Blasco D, Roy SO, St-Amand L, Lagacé $\mathrm{B}$, Lee K, Gagné JP (1996a) $\mathrm{CO}_{2}$ production predicted from isocitrate dehydrogenase activity and bisubstrate enzyme kinetics in the marine bacterium Pseudomonas nautica. Aquat Microb Ecol 11:11-19

Packard TT, Berdalet E, Blasco D. Roy SO, St-Amand L, Lagacé B, Lee K, Gagné JP (1996b) Oxygen consumption in the marine bacterium, Pseudomonas nautica predicted from ETS activity and bisubstrate enzyme kinetics. J Plankton Res 18:1819-1835

Parsons TR, Maita Y, Lalli CM (1984) A manual of chemical and biological methods for seawater analysis. Pergamon Press, Oxford

Savenkoff C, Vézina AF, Chanut JP, Gratton Y (1995) Respiratory activity and $\mathrm{CO}_{2}$ production rates of microorganisms in the lower St. Lawrence Estuary. Cont Shelf Res 15 613-631

Walsh K, Koshland DE Jr (1984) Determination of flux through the branch point of two metabolic cycles. J Biol Chem 259:9646-9654

Submitted: November 25, 1997; Accepted: August 10, 1998

Proofs received from author(s): March 24, 1999 